\title{
o Sétimo Selo, de Ingmar Bergman, e as bases metafísicas da ciência moderna
}

\section{MÁRCIO BARRETO}

\section{Resumo}

Explorando as potencialidades do cinema para dar a ver aquilo que excede a representação na tela e o próprio campo perceptivo do espectador, o filme O Sétimo Selo, de Ingmar Bergman, por meio de conexões mais temáticas do que audiovisuais, é aqui tomado como fio condutor das articulações entre as bases metafísicas da ciência moderna e a construção da oposição entre cultura e civilização. Outros filmes pontuam a análise que parte do triunfo da teoria gravitacional de Isaac Newton em direção ao largo espectro de percepções visuais sobre a cultura ocidental oferecido por O Sétimo Selo, do Gênesis ao Apocalipse, da aurora da ciência moderna à bomba atômica.

Palavras-chave:

Cinema, percepção da ciência, metafísica 


\title{
The Seventh Seal, by Ingmar Bergman, and the metaphysical foundations of modern science
}

\author{
MÁRCIO BARRETO
}

\begin{abstract}
Exploring the potential of cinema to make the spectator see what transcends the representation and even spectator's perceptive field, The Seventh Seal, directed by Ingmar Bergman, through connections more thematic than audiovisuals, guides the analysis of the relations between metaphysical foundations of modern science and the construction of the opposition between culture and civilization. Other films support the analysis that begins with the triumph of Isaac Newton's gravitational theory toward the large spectrum of visual perceptions about Western culture offered by The Seventh Seal, from the Genesis to the Apocalypse, from the dawn of modern science to the atomic bomb.
\end{abstract} Keywords: 


\section{El Séptimo Sello, de Ingmar Bergman, y las bases metafísicas de la ciencia moderna}

\section{MÁRCIO BARRETO}

\section{Resumen}

Aprovechando las potencialidades del cine para mostrar aquello que va más allá de la representación en la pantalla y el propio campo perceptivo del espectador, la película El Séptimo Sello, de Ingmar Bergman, mediante conexiones más temáticas que audiovisuales, es aquí tratada como hilo conductor de las articulaciones entre las bases metafísicas de la ciencia moderna y la construcción de la oposición entre cultura y civilización. Otras películas tratan del análisis que parte del triunfo de la teoría de la gravedad de Isaac Newton hacia el amplio ámbito de percepciones visuales sobre la cultura occidental que ofrece El Séptimo Sello, del Génesis al Apocalipsis, de la aurora de la ciencia moderna a la bomba atómica.

Palabras clave:

Cine, percepción de la ciencia, metafísica 


\section{O racionalismo científico em questão}

Em A revolução das órbitas celestes, logo após o diagrama de círculos concêntricos que expõe o novo sistema de mundo, Copérnico faz referência a Hermes Trismegisto como o construtor do Templo do Sol.

No meio de todos encontra-se o Sol. Ora, quem haveria de colocar neste templo, belo entre os mais belos, um tal luzeiro em qualquer outro lugar melhor do que aquele onde ele pode iluminar todas as coisas ao mesmo tempo? Na verdade, não sem razão, foi ele chamado o farol do mundo por uns e por outros a sua mente, chegando alguns a chamar-lhe seu Governador. [Hermes] Trismegisto apelidou-o de Deus visível... (COPÉRNICO, 1984, p. 53)

Como na Renascença acreditava-se que Hermes Trismegisto era um egípcio, alguns o comparavam a Moisés. Há no piso da catedral de Siena um mosaico do ano de 1480 que retrata Hermes Trismegisto com uma inscrição sob seus pés: Hermes Mercurius, Contemporaneous Moyse.

Esta representação de Hermes Trismegisto num edifício cristão, colocada justo à entrada, de modo tão relevante, não é um fenômeno local e isolado, mas um símbolo do apreço com que o encarava a Renascença Italiana e uma profecia do que seria sua brilhante e pouco comentada carreira pela Europa nos séculos seguintes (YATES, 1987, p. 56).

Antes de Copérnico, no século XIII, o poeta sufi Mevlana Jalaluddin Rumi colocava o Sol em posição central em seus po- 
emas místicos. Rumi criou o Sama, dança mística na qual os adeptos giram como planetas em torno de si próprios e de um sol espiritual. Para Rumi (1981), os dervixes girantes participam da natureza de todas as escalas dos movimentos cósmicos.

A importância desses textos místicos não se restringe às suas influências na obra de Copérnico. Giordano Bruno viajava pela Europa propagando o hermetismo e, para Newton, como revelaram os estudos de Betty Dobbs (1984), a Alquimia não foi menos importante. O teórico da Economia John M. Keynes declarou em 1942 que "Newton não foi o primeiro da idade da razão, mas foi o último dos magos" (KEYNES, 1972, p. 16). Newton possuía em Cambridge um laboratório para experiências alquímicas e uma rica biblioteca sobre o tema. Examinou as seções mais esotéricas da literatura alquímica, e sua carreira, após 1675 , pode ser interpretada como um longo esforço para unir Teologia, Alquimia e Filosofia Mecânica.

O que está em cima é como o que está embaixo. Esta frase, máxima dos alquimistas, abre a Tábua de esmeralda, a qual é atribuída a Trismegisto. A frase sintetiza também a ousadia de Newton ao explicar os movimentos dos corpos celestes, como o da Lua ao redor da Terra e o dos planetas ao redor do Sol, por uma força da mesma natureza daquela que regula a queda de um objeto na superfície da Terra. Inspirado em místicos como Jacob Boehme e Trismegisto, Newton fragiliza a milenar fronteira que a tradição judaico-cristã coloca entre céu e terra e subverte a verticalidade da filosofia platônica que opõe a experiência visceral no mundo terreno aos ideais de beleza e de verdade contemplados pela elevação da alma dos amantes à região supraceleste.

Das bases metafísicas da ciência moderna, no entanto, mal se podem encontrar os rastros na prática científica contemporânea. Alexandre Koyré (1968) atribuiu essa espécie de visão desencantada do mundo ao triunfo da ciência moderna, processo que teve seu coroamento com a teoria gravitacional de Newton. O filósofo japonês Keiji Nishitani (1982) atrelou a dessacralização da cultura ocidental à prevalência do caráter utilitário assumido pela tecnociência.

Desde o advento da era moderna, a visão da ciência tem sido amarrada à questão do ateísmo. A rejeição da existência de um Deus personificado emerge como consequência da rejeição de uma visão teológica do mundo. Genericamente falando, este ateísmo tem se tornado o ponto de vista do racionalismo cien- 
tífico. Seu conteúdo sintetiza-se numa forma de materialismo. E seu espírito é o "progresso" (NISHITANI, 1982, p. 53).

Para o filósofo da Escola de Kyoto, o conflito entre o viés exclusivamente científico da natureza e as concepções de mundo da religião tradicional, em particular do cristianismo, traz à tona a questão da visão de mundo do homem moderno, que subtrai das coisas suas essências na busca do prazer como escudo contra a dor, transformando a subjetividade na armadilha em que o desejo egocêntrico é traduzido na sensação de falta insaciável.

Pressionados pelo desenvolvimento da tecnociência, até os filósofos do existencialismo e da fenomenologia aceitaram a separação entre tecnologia e cultura, segregação cara à filosofia alemã, especialmente a de Heidegger. Nessa ótica, os objetos técnicos são tratados exclusivamente como utensílios que servem às práticas humanas e que respondem às necessidades da civilização, como se a cultura devesse ser protegida do avanço da técnica, como se entre a técnica e a cultura existisse uma fronteira que devesse ser preservada, sob pena de a cultura ser devastada pela galopante ascensão da tecnologia. À sombra desse temor, o sagrado ficou estritamente ligado à prática contemplativa e a técnica, às atividades operatórias.

O filósofo francês Gilbert Simondon se debruça sobre essa questão afirmando que "não é possível conceber a tecnicidade conservando a pressuposição dualista que opõe contemplação e operação" (SIMONDON, 2013, p. 97). Em ressonância com o pensamento de Nishitani, Simondon ressalta:

O homem moderno, ao mesmo tempo, da mesma maneira e pela mesma razão, degrada a tecnicidade e a sacralidade. Ele as degrada por utilizá-las numa situação de ansiedade, pois sente sua existência e seu prestígio ameaçados [...] (SIMONDON, 2013, p. 80).

Sacralidade e tecnicidade passam a formar opostos da cultura ocidental que se degradam, respectivamente, pela fragmentação do ritual religioso e pelo recalque da magia inerente à técnica nos fetiches que a mercadoria promove. A perversão do mundo mágico primitivo da técnica é potencializado na convergência entre os caminhos da tecnociência e do capital.

Em As duas fontes da moral e da religião, Henri Bergson formulou com lucidez o desenvolvimento tecnocientífico 
orientado pelo descarte das virtudes das bases metafísicas da ciência, especialmente a partir da Revolução Industrial.

Se nossos órgãos são instrumentos naturais, nossos instrumentos são por isso mesmo órgãos artificiais. [...] Porém, máquinas que [...] convertem em movimento energias potenciais acumuladas durante milhões de anos, vieram dar ao nosso organismo uma extensão tão vasta e uma potência tão formidável, tão desproporcional à sua dimensão e força, que certamente nada disso havia sido previsto no plano estrutural de nossa espécie: foi um acaso único, a maior conquista material do homem no planeta. [...] Ora, nesse corpo desmesuradamente aumentado, a alma continua o que era, demasiado pequena agora para enchê-lo, muito frágil para dirigi-lo. Daí o vácuo entre o corpo e a alma. Daí os terríveis problemas sociais, políticos, internacionais, que são outras tantas definições desse vazio e que, para enchê-lo, provocam hoje tantos esforços desordenados e ineficazes: para isso seriam necessárias novas reservas de energia potencial, mas agora de natureza moral (BERGSON, 1978, p. 256-257).

Bergson teve a preocupação de estender o significado da ciência para além das fronteiras da inteligência, propondo, no encontro que teve com Einstein durante a conferência do Collège de France em abril de 1922, que o método da intuição poderia oferecer a correlação entre o tempo matemático da Teoria da Relatividade e a multiplicidade de contrações da duração. Ainda que o diálogo entre o físico e o filósofo tenha sido pouco profícuo, a atual questão da interioridade do tempo sugere a "complementaridade entre a ciência e a metafísica proposta por Bergson como necessária para a compreensão da complexidade dos problemas contemporâneos" (BARRETO, 2016, p. 77).

\section{O cinema excedendo o campo visual na percepção sobre a ciência}

O cinema surge na derrocada do tempo absoluto newtoniano, poucos anos antes da publicação da teoria da Relatividade Especial. A virada do século XIX para o século XX é marcada por obras em que o tempo é repensado por Einstein, Proust, Bergson, Virginia Woolf, entre outros. O cinema fez dele sua matéria-prima. Andrei Tarkovsky (1990) definiu o trabalho do diretor de cinema como o de um escultor do tempo. 
Cinema e ciência compartilham muitos pressupostos. Como apontou Gilles Deleuze (1983), a ciência fez do tempo uma variável independente: todo instante $(\mathrm{t})$ é equidistante de dois outros quaisquer, um anterior e outro subsequente. Analogamente, o que tornou possível o cinema foi a segurança da equidistância das imagens fotográficas, as quais, graças à perfuração da fita onde são perfiladas, podem ser exibidas num fluxo constante. Bergson já havia notado no mecanismo do cinematógrafo um reflexo da racionalidade científica: o cinema opera a reconstituição artificial do movimento a partir de imagens imóveis tal como a concepção científica do instante $(\mathrm{t})$, o qual, representado por um ponto imóvel numa reta, é um artifício que retira do tempo sua essência, seu fluxo ininterrupto. "No que diz respeito ao tempo, a ciência conta os instantes, marca as simultaneidades, mas segue sem apreciar o que se passa durante os intervalos" (BERGSON, 1999, p. 57).

Ilya Prigogine e Isabelle Stengers ressaltaram outro fundamento da ciência moderna que a aproxima do cinema: a reversibilidade do tempo. Tal como é tecnicamente permitido no cinema, a projeção de um filme no sentido inverso ao da filmagem, a dinâmica define como matematicamente equivalentes os dois sentidos do fluxo do tempo, pois "faz da reversibilidade a propriedade de toda evolução dinâmica" (PRIGOGINE; STENGERS, 1984, p. 47).

Por seu parentesco com a ciência e por sua aptidão para o simples entretenimento, o cinema poderia seguir apenas suas vocações iniciais ligadas à instrumentação de pesquisas de cientistas como Étienne-Jules Marey e Albert Londe ou à mercantilização do divertimento. Mas a potencialidade da técnica cinematográfica vai além do vínculo sensório-motor que estabelece com o espectador, pois o cinema explora diretamente o tempo ao criar novas realidades capazes de subverter cronologias.

O cinema poderia apenas encarnar a degradação da tecnicidade e da sacralidade, mas revela-se também como possibilidade de percepção e de reconfiguração do que na ciência e na religião foi reprimido após o advento da ciência moderna. Filho da ciência e pai de uma nova arte, o cinema opera entre o caráter estático da escultura no espaço e a fluidez fugitiva do tempo. A imagem-tempo, termo cunhado por Deleuze (2005), rompe o circuito sensório-motor do espectador para dar-lhe a percepção daquilo que não seria possível sem o cinema. 
Em seu livro $O$ cinema pensa, o filósofo Julio Cabrera (2006) chama de conceito-imagem aquilo que no cinema é instaurado no contexto da experiência do espectador, aquilo que transcende o componente lógico da palavra e, podemos acrescentar, da própria imagem.

Os conceitos-imagens do cinema, por meio desta experiência instauradora e plena, procuram produzir [...] um impacto emocional que, ao mesmo tempo, diga algo a respeito do mundo, do ser humano, na natureza etc. e que tenha um valor cognitivo, persuasivo e argumentativo através de seu componente emocional (CABRERA, 2006, p. 22).

O estímulo da percepção pode vir da emoção associada ao pensamento lógico, como afirma Cabrera, mas a operação mais importante se dá na multiplicidade de agenciamentos que a modulagem do tempo possibilita dentro e fora do campo perceptivo. A relação entre a carga emocional de um filme e seu efeito cognitivo não é linear. $\mathrm{O}$ engate do espectador na temporalidade do filme lhe permite o acesso a diferentes percepções da realidade. Ainda que não elaboradas intelectualmente, ainda que inconscientes, são percepções excedentes, além do sensato e do mensurável, residuais em relação ao processo representativo, irradiações de sentido e de afeto, de emoção e de percepção.

O cinema é capaz de arrebatar o espectador numa experiência que excede a representação. A própria percepção, segundo o filósofo Renaud Barbaras, é uma experiência incompleta por ter "um caráter transcendente, no sentido que excede as potencialidades que aparecem num primeiro plano que não esgotam a realidade daquilo que é percebido" (BARBARAS, 2011, p. 150-151).

O cinema tem ascendência científica, mas os meios artificiais pelos quais o cinema se concretiza não implicam a artificialidade do seu resultado: a imagem-movimento, o corte móvel, confere ao cinema a possibilidade de uma nova percepção da realidade, ou ainda a criação de uma nova realidade. Como observou Arlindo Machado, "se a percepção do movimento é uma síntese que se dá no espírito e não no mecanismo do olho, o cinema deve ser entendido também como um processo psíquico, um dispositivo projetivo que se completa na máquina interior" (MACHADO, 2013, p. 23). 


\section{O Sétimo Selo e a exposição dos fundamentos da cultura ocidental}

Nos filmes de Ingmar Bergman, existem poucos elementos que levam o espectador à direta reflexão sobre a ciência ou à percepção da ciência como componente da trama. No entanto, como em Fanny e Alexander, Morangos silvestres, $O$ olho do Diabo, entre outros, a ciência é agenciada em manifestações de arquétipos e na tensão entre o sagrado e o profano. Especialmente em $O$ Sétimo Selo, na voltagem entre a crua e racionalizada realidade que se impõe aos olhos de Antonius Block e a inverossimilhança das visões do malabarista Jof, a ciência moderna aparece em estado embrionário. Os diálogos entre a morte e os outros personagens precipitam e subvertem o encontro do espectador com aquilo que ele percebe como realidade e o remetem ao drama do homem moderno confinado no tabuleiro de um jogo de xadrez.

Os pensamentos que açoitam o espírito do cavaleiro recém-chegado de uma das Cruzadas têm a dúvida como chicote e são metaforicamente encarnados nos pernilongos que picam Jof dentro da coroça em que dorme a trupe de artistas itinerantes. No entanto, ao contrário de Block, que se afunda na armadilha da impotência do pensamento para dirimir a dúvida gerada pela mal formulada questão sobre a existência de Deus, Jof mata o inseto que o atormenta e o abandona sem demora.

Em sua pretensão de olhar a natureza de um ponto de vista dominador, o homem moderno, confiando na racionalidade científica, chamou para si as responsabilidades de formular e de responder às questões universais, mas substituiu enigmas de fenômenos naturais pelo que Koyré chamou de "enigma de si próprio" (KOYRÉ, 1968, p. 84): no espesso silêncio da escuridão noturna, como o príncipe Hamlet na obra de Shakespeare, o homem moderno ricocheteia nas peças do tabuleiro da mente, açoitado pelos intermitentes zunidos dos pernilongos-pensamentos.

Hamlet foi escrito entre 1599 e 1601, aproximadamente 50 anos após a publicação de De revolutionibus orbium coelestium, de Nicolau Copérnico, e por volta de 30 anos antes da publicação de Dialogo sopra i due massimi sistemi del mondo, de Galileu Galilei. Shakespeare coloca nos lábios do príncipe da Dinamarca a dúvida que o paralisa tal como imobilizado fica o cavaleiro Antonius Block: "[...] o matiz natural da decisão se transforma no doentio pálido do pensamento. E empreitadas 
de vigor e coragem, refletidas demais, saem de seu caminho, perdem o nome de ação" (SHAKESPEARE, 2011, p. 66).

As hesitações de Hamlet e de Block irrompem também como a chaga da visão predominante do racionalismo científico. Em Hamlet, afirma Laymert Garcia dos Santos, "a dúvida atroz surge como uma trinca no próprio ser do homem. Entregue às suas forças, o homem acaba perdendo a fé em si mesmo. Ficam a carne, o pensamento e o sofrimento que o pensamento inflige à carne" (SANTOS, 1990, p. 210).

A peça de Shakespeare entra na narrativa de Fanny e Alexander: o pai de Alexander morre interpretando grotescamente o rei Hamlet. O próprio Alexander, então, incorpora o drama do príncipe da Dinamarca dialogando com o fantasma do pai. No entanto, O Sétimo Selo traz de maneira mais contundente, ainda que implícita no tormento de Antonius Block, uma ressonância com os fantasmas que perturbam Hamlet. E o espectador se vê, em última análise, diante do contraste entre o que Nishitani chamou de ateísmo do racionalismo científico e a visão encantada que Jof tem do mundo.
Figura 1:: A atriz Maud Hansson em O Sétimo Selo.

Fonte: <https://reynoldsukmedia.files.wordpress.com/2015/o1/ screen-shot-2014-08-14at-15-09-16.png>. Acesso em: 30 nov. 2017

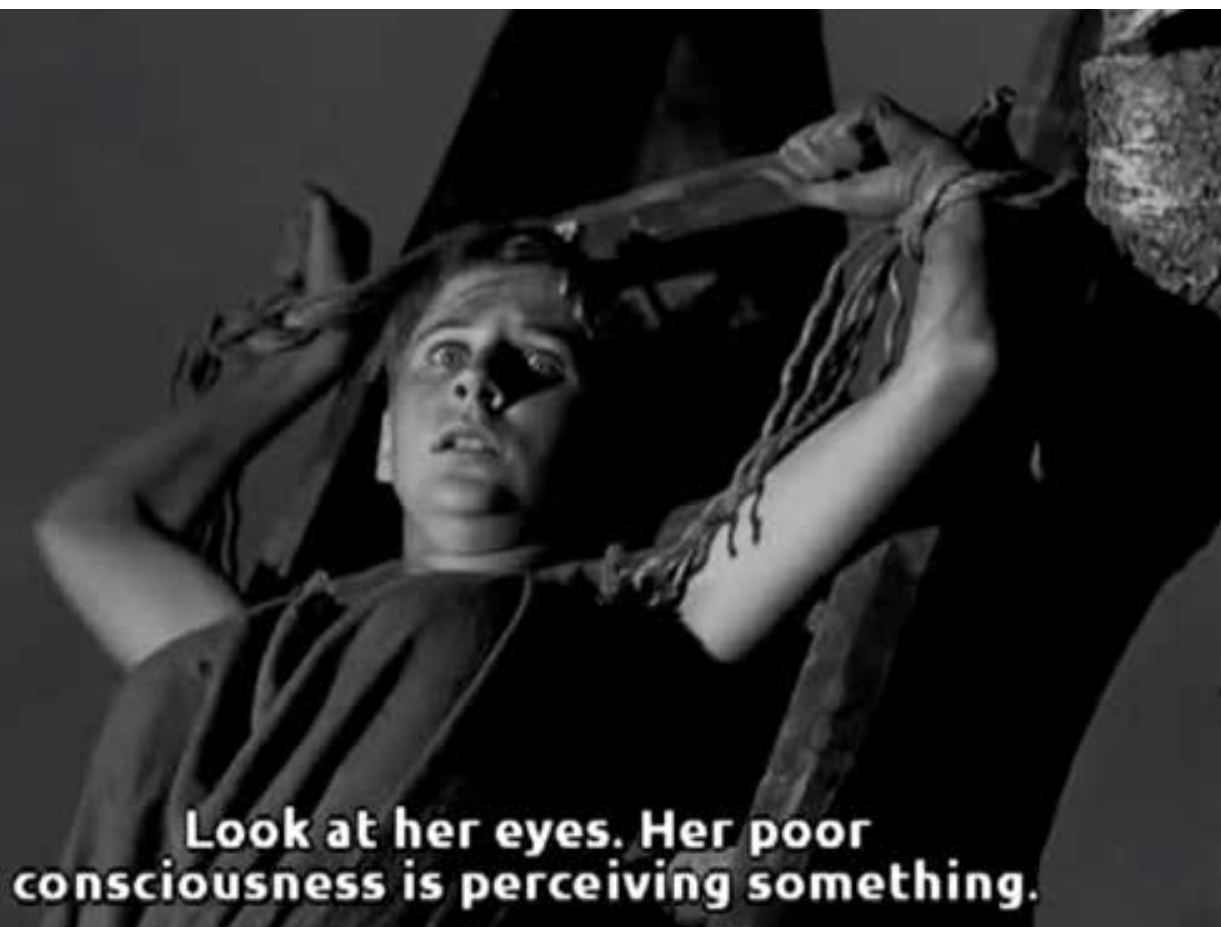


Deus e Demônio, céu e terra, altura e queda, entre outros, são elementos caros à ciência que pontuam o filme de Bergman e tantos filmes importantes da história do cinema, nos quais o espectador é tocado por percepções sobre a ciência, sem que elas se completem através de suas respectivas elaborações intelectuais, e que poderão no futuro se atualizar num leque abrangente de possibilidades em outros encontros com a ciência.

Em O Sétimo Selo, o olhar apavorado que a atriz Maud Hansson empresta à jovem 'bruxa', no momento em que é amarrada a uma espécie de mastro e erguida sobre a lenha que queimará juntamente com seu corpo, deve-se à súbita conscientização de que o Demônio pelo qual estaria possuída não a protegerá da ignorância dos homens. Olhando para baixo, percebe a altura a que se elevou em sua fantasia de ter sido eleita pelo Demônio. Com a vertigem do tombo iminente, teme a gravidade em seu corpo.

Em Um corpo que cai, de Hitchcock, o medo irracional de altura que assola John 'Scottie' Ferguson traduz-se na conscientização da gravidade em seu corpo, vertigem mórbida como a da jovem queimada em O Sétimo Selo. Scottie está atado à racionalidade, mas a energia que permitiu a solução racional do suspense é obtida a partir do que fugiu do controle de pensamento disciplinado pela razão. Ao contrário de Antonius Block, cuja razão sucumbe diante da dúvida que o atormenta, Scottie coloca a racionalidade a serviço do controle das forças que o levam à vertigem. A miragem da saída de Madeleine do toalete do hotel com o cabelo preso será rapidamente convertida na clareza que a observação do colar que ligava todos os pontos lhe dá.

Figura 2: A atriz Kim Novak em Um corpo que cai

Fonte: <http://blogues. publico.pt/camaraescura/ files/2012/12/13_5311_FS_o031C. jpg >. Acesso em: 30 nov. 2017.

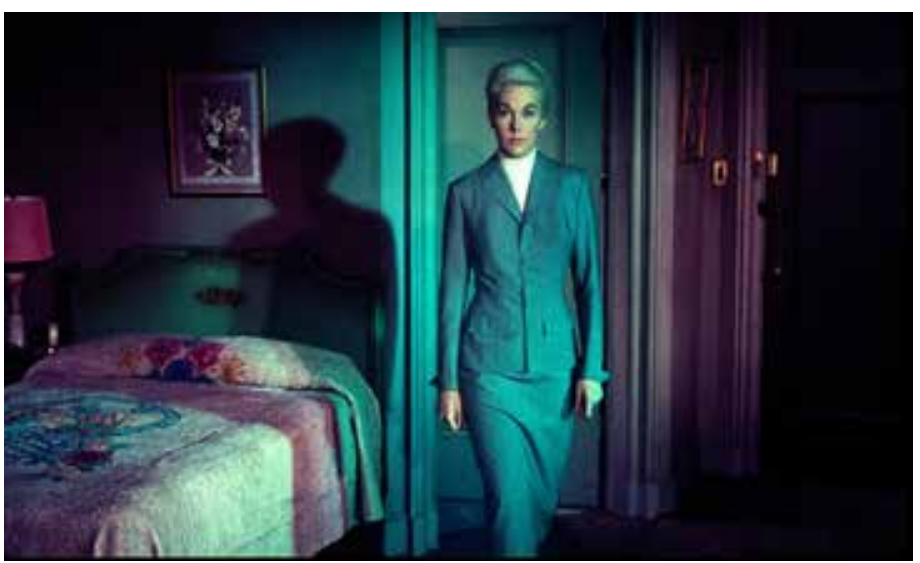


A insistente lembrança da queda e da morte de um colega desencadeia a acrofobia de Scottie, superpondo-se anarquicamente em sua memória com a queda de Madeleine, subvertendo o tempo que se mostra organizado nos círculos concêntricos das sequoias.

A queda exerce inegável protagonismo na cultura ocidental: a Expulsão do Paraíso no Gênesis e a Gravitação Universal de Newton têm na queda um elemento central, sem contar sua importância germinal para Einstein na concepção da Teoria da Relatividade Geral. No Ocidente, a ciência e a tradição judaico-cristã têm a queda de uma maçã como espécie de arquétipo que as une, embora não haja qualquer referência a maçãs no Gênesis, tampouco na obra de Newton.

A sobredeterminação dos arquétipos já foi estabelecida por Jung (2000), de modo que um arquétipo não é jamais o conceito ou o preceptor de uma única coisa, mas uma imagem que condensa diversas situações em uma só representação. É na maçã arquetípica da cultura ocidental que religião e ciência se encontram para se distinguirem. A maçã de Adão e Eva tem em sua polpa a Queda do Paraíso e a lendária queda da maçã de Newton representa, a um só tempo, o triunfo da ciência moderna e a subsequente intensificação da oposição entre civilização e cultura.

Como afirmou Zizek (1988), a queda é uma iguaria filosófica em Um corpo que cai. Podemos saboreá-la também em outros filmes: O Anticristo, de Lars Von Trier, tem como mote o Pecado Original, a queda tão inexoravelmente para baixo quanto o tempo passa irreversivelmente para frente, mas foi Wim Wenders que provavelmente reconheceu em maior profundidade a relevância do tema da gravidade exercida no corpo humano em Asas do desejo e em Tão longe, tão perto.

Lançado em 1987, na iminência da queda do muro de Berlim, três décadas após os lançamentos de $O$ Sétimo Selo e Um corpo que cai, Asas do desejo funde múltiplos planos do real agenciados pela poesia de Rainer Maria Rilke, pelo rock de Nick Cave, pela memória da Guerra que passa diante da visão dos anjos, pelos ecos do pensamento de Walter Benjamin personificados no velho narrador. A eternidade não linear dos anjos estabelece uma voltagem com a temporalidade dos encarnados, bem como há tensão entre o céu em que flutuam os anjos e o chão que atrai implacavelmente o corpo humano.

A primeira evidência da queda de Damiel é a gravidade em seu corpo denunciada pelas pegadas que deixa na areia 
das proximidades do muro de Berlim. A partir de então, ele passará a ocupar-se com o advento do aqui e do agora, como se entendesse de imediato que, para bem encarnar, é melhor manter quieto o pensamento. Peter Falk é personagem de si próprio no filme de Wim Wenders e transita habilmente entre o anjo de outrora, sua encarnação na pele de ator e o personagem Columbo da série televisiva, dissolvendo a fronteira entre ficção e realidade na sintonia entre sua própria duração e o devir universal.

Damiel e Peter Falk caem no vórtice do tempo e sentem a gravidade como vínculo universal do corpo. $\mathrm{O}$ mesmo não acontecerá com Cassiel em Tão longe, tão Perto, que encarna sentindo o vetor da gravidade fincado em seu corpo sem asas como uma espada a anunciar o destino inevitável para o solo. Cassiel não encarna bem. O vício se sobrepõe à virtude, e a racionalidade por ele invocada é impotente para dar ao tempo um sentido para frente e à gravidade um sentido para baixo. A queda não é completa: o desejo de ter o corpo numa relação cósmica universal hesita diante do desconforto da perda da eternidade. Entre Damiel e Cassiel, há a diferença entre a dúvida e a quietude do pensamento, entre o tormento hamletiano do cavaleiro Antonius Block e a pureza nada ingênua do malabarista Jof.

Tão longe, tão perto foi realizado no contexto da queda do muro de Berlim e dá continuidade a Asas do desejo, com a participação, entre outros, de Mikhail Gorbachev e Lou Reed. Apropriadamente, Lou Reed entoa ao decaído Cassiel a canção Why can't I be good, de sua autoria:

\footnotetext{
Why can't I be good

Why can't I act like a man

Why can't I be good

And do what other men can

Why can't I be good

Make some thing of this life
}

A gravidade no corpo humano, alegoria central em Asas do desejo, tem ênfase ainda maior em Tão longe, tão perto nas cenas da queda do suicida, dos acrobatas em elásticos, do transporte da carga contrabandeada e do homem velho que sussurra agonizando após ser atingido por uma bala: $f$ nalmente, me sinto pesado. Do pó vieste e ao pó retornarás (GÊNESIS, 3:19): o velho volta ao chão, resigna-se diante da impossibilidade de continuar seu esforço ascensional e de- 
sencarna sentindo finalmente seu peso que lhe permite ser um veículo para a obra do tempo.

Asas do desejo e Tão longe, tão perto fazem emergir da tela a gravidade como possível elo entre ciência e metafísica, tal como Newton, em sua concepção teológica de mundo, em sua busca pelo discurso de Deus escrito no comportamento da natureza, formulou matematicamente a lei da atração gravitacional. A síntese newtoniana que uniu céu e terra é também a síntese entre as visões científica e teológica do mundo.

Em O Sétimo Selo, a Vontade de Potência nietzschiana que atravessa o malabarista Jof passa ao largo de dogmas e de códigos morais, como na cena em que ele rouba o bracelete na taverna sem que isso o comprometa moralmente. Apenas fluindo nos acontecimentos, Jof vê o que os personagens aflitos e tementes não podem perceber pela cegueira da rigidez da razão que formula os dogmas religiosos através de relações entre causa e efeito, como a da penitência em decorrência do ato pecaminoso.

No filme de Bergman, ambientado na época que precedeu o advento da ciência moderna e realizado pouco tempo após as explosões das bombas atômicas em Hiroshima e Nagasaki, a forte referência ao Apocalipse de João de Patmos pode curto-circuitar no espectador o arco entre a ameaça de destruição em massa da Peste e a da bomba atômica. Seria leviano afirmar que a bomba atômica representou o ápice do processo de expurgo das bases metafísicas da ciência, mas a era atômica explicitou a hipótese bergsoniana de que a técnica, como extensão do nosso corpo, conferiu-lhe "uma extensão tão vasta e uma potência tão formidável, tão desproporcional à sua dimensão e força, que certamente nada disso havia sido previsto no plano estrutural de nossa espécie" (BERGSON, 1978, p.256).

Na nona das "Teses para a era atômica", Gunther Anders diz que, na era atômica, nos tornamos Utopistas Invertidos: "enquanto os utopistas comuns são incapazes de produzir de fato o que são capazes de imaginar, nós somos incapazes de imaginar o que estamos de fato produzindo" (ANDERS, 1962, p. 493). Bergson ainda dirá que "nesse corpo desmesuradamente aumentado, a alma continua o que era, demasiado pequena agora para enchê-lo, muito frágil para dirigi-lo" (BERGSON, 1978, p. 257): o vácuo entre corpo e alma a que se refere Bergson bem antes do advento da bomba atômica e a utopia invertida de Anders talvez contenham rastros do processo de expurgo da metafísica da física, algo deixado para 
trás e que emerge num momento de ruptura, algo semelhante ao que se passa, no filme de Bergman, entre o olhar da Morte e o de suas vítimas.

A profecia bíblica do Apocalipse, em que a abertura do Sétimo Selo traz o soar das trombetas dos anjos e o Juízo Final, é repleta de elementos mágicos que são colocados entre outros elementos que já figuravam nas profecias de Daniel: desejos de vingança, bestas e autoglorificação de santos e mártires. Expurgados do texto ou distorcidos todos os vestígios do paganismo, "como cansam, no Apocalipse, essas desgraças e pragas e mortes" (LAWRENCE, 1990, p. 88). Lawrence continua: "O Apocalipse nos mostra aquilo contra o qual estamos resistindo, de modo antinatural: nossa ligação com o cosmo, com o mundo, com a humanidade, com a nação, com a família" (LAWRENCE, 1990, p. 120). O Sétimo Selo é referenciado no Apocalipse e apocalipse quer dizer revelação: no filme, a gravidade é revelada para o acrobata, de cujo corpo ela é cúmplice, como possibilidade de encantamento do mundo.

Hitchcock e Wim Wenders reverberam a questão da gravidade em seus filmes, mas Bergman foi o que pegou pela garganta o drama do homem moderno, sintetizando num pernilongo o arquétipo do fruto do conhecimento e, num tabuleiro de xadrez, a profecia do Apocalipse. Mas também foi o que mais sinalizou, principalmente através de Jof, a salvação pela via da religação com o cosmo, do resgate das raízes pagãs do cristianismo, como fez Lawrence em seu último texto, Apocalipse, escrito pouca antes de sua morte, a 2 de março de 1930.

O último de texto de Isaac Newton foi sobre o mesmo tema: As profecias de Daniel e o Apocalipse de São João, escrito em 1733. A coincidência pode ser conjecturada pela convicção que Newton e Lawrence tinham da sacralidade na relação do ser com o cosmo, na religação entre o ser e o cosmo. Em O Sétimo Selo, a percepção do espectador sobre esses temas é estimulada pelo aparato tecnológico do cinema que atualiza o que Gilbert Simondon (1969) chamou de mundo mágico primitivo, pré-técnico e pré-religioso.

O cinema, na incompletude da percepção do espectador, pode agenciar aspectos do real e do real imaginado que escapam da intencionalidade de produtores e diretores de filmes. Pode produzir encanto, arrebatamento, ou seja, muito mais do que induzir um significado cognitivo através de seu componente emocional.

Incontáveis obras lapidadas no tempo pelo cinema deslocam o olhar do espectador daquilo que Nishitani chamou de 
ponto de vista do racionalismo científico, muitas vezes levando o espectador a níveis refinados de percepções pouco ortodoxas sobre a ciência: as luzes cintilantes no mar em Limite, obra-prima de Mario Peixoto; as luzes que brilham nas ruas molhadas de Taxi driver; as passagens da realidade aos sonhos nos musicais de Gene Kelly e Fred Astaire; o transe de Saartjie Baartman em Vênus negra; os pesadelos de Molholland Drive; o cristal de tempo em Cidadão Kane; a viagem cósmica do retorno de David para casa de 2001, Uma odisseia no espaço; o oceano de memória que salpica pontos brilhantes do passado em Solaris; a cidade em movimento de Koyanannisqatsi; os filmes de Ozu, nos quais a câmera é colocada na altura dos olhos de uma pessoa em posição de lótus; a iluminação do quarto de hotel de Um corpo que cai; as auscultas dos anjos em Asas do desejo; a visão de Jof da Virgem Maria em O Sétimo Selo; as pinturas rupestres de A caverna dos sonhos esquecidos, entre incontáveis outras.

O cinema brota na cultura ocidental como análogo do xamanismo em sua capacidade de ensinar a sonhar e de reconstituir sonhos esquecidos pelo espírito de progresso que se apropriou do racionalismo científico. O líder ianomâmi Davi Kopenawa descreve cinematograficamente a técnica do sonho.

Os espíritos xapiripë dançam para os pajés desde o primeiro tempo e assim continuam até hoje. Eles parecem seres humanos mas são tão minúsculos quanto partículas de poeira cintilantes. Para poder vê-los deve-se inalar o pó da árvore yãkõanahi muitas e muitas vezes. Leva tanto tempo quanto para os brancos aprender o desenho de suas palavras. $\mathrm{O}$ pó do yãkõanahi é a comida dos espíritos. Quem não o «bebe» assim fica com olhos de fantasma e não vê nada.

Os xapiripë dançam juntos sobre grandes espelhos que descem do céu. Nunca são cinzentos como os humanos. São sempre magníficos: o corpo pintado de urucum e percorrido de desenhos pretos, suas cabeças cobertas de plumas brancas de urubu rei, suas braçadeiras de miçangas repletas de plumas de papagaios, de cujubim e de arara vermelha, a cintura envolta de rabos de tucanos.

Milhares deles chegam para dançar juntos, agitando folhas de palmeiras novas, soltando gritos de alegria e cantando sem parar. Seus caminhos parecem fios de aranhas brilhando como a luz do luar e seus ornamentos de plumas mexem lentamente ao ritmo de seus passos. Dá alegria de ver quanto são bonitos! 
Os brancos desenham suas palavras porque seu pensamento é cheio de esquecimento. Nós guardamos as palavras dos nossos antepassados dentro de nós há muito tempo e continuamos passando-as para os nossos filhos. As crianças, que não sabem nada dos espíritos, escutam os cantos do pajés e depois querem ver os espíritos por sua vez. É assim que, apesar de muito antigas, as palavras dos xapiripë sempre voltam a ser novas. São elas que aumentam nossos pensamentos. São elas que nos fazem ver e conhecer as coisas de longe, as coisas dos antigos. É o nosso estudo, o que nos ensina a sonhar. Deste modo, quem não bebe o sopro dos espíritos tem o pensamento curto e enfumaçado; quem não é olhado pelos xapiripë não sonha, só dorme como um machado no chão (KOPENAWA, 1998, p. 8).

Em Xapiri (Bruce Albert, Laymert Santos, entre outros; Brasil, 2012), filme sobre o xamanismo ianomâmi, a câmera percorre o espaço-tempo do encontro de 37 xamãs na aldeia de Watoriki, Roraima, em março de 2011. O filme vai além de um documentário, pois realiza, com efeitos inebriantes produzidos pelo tratamento das imagens, a dissolução das fronteiras entre o xamanismo e a técnica cinematográfica ou, no sentido simondoniano, entre cultura e civilização. Sobreposições e deformações das imagens geram a imersão profunda do espectador no refinamento da técnica ianomâmi. A cena final, com crianças ianomâmis a brincar numa árvore, é de beleza indescritível.

O Setimo Selo não tem o colorido das palavras de Kopenawa ou das imagens de Xapiri, mas é policromático em seu espectro de virtuais percepções, que vão do Gênesis ao Apocalipse, da aurora da ciência moderna à bomba atômica. Na essência do cinema, como na teoria de Newton, ciência e metafísica mal se distinguem.

\section{Referências}

ANDERS, Gunther. Teses para a era atômica. The Massachusetts Review; v. 3, n. 3, 1962.

BARBARAS, Renaud. Investigações fenomenológicas: em direção a uma fenomenologia da vida. Curitiba: Editora da UFPR, 2011.

BARRETO, Márcio. Por que revisitar o debate entre Bergson e Einstein? Trans/Form/Ação, Marília, v. 39, n. 1, p. 77-92, jan./mar. 2016. 
BARTHES, Roland. La chambre clair. Paris: Gallimard, 1980. BAUDRY, Jean-Louis. Le dispositif: approches metapsycologiques de l'impression de realité. Paris: Communications, 1975.

BERGSON, Henri. As duas fontes da moral e da religião. Rio de Janeiro: Zahar, 1978.

. Durée et simultanéité. Paris: Quadridge/P.U.F., 1999. . A evolução criadora. Lisboa: Edições 70, 2001.

CABRERA, Julio. $O$ cinema pensa. Uma introdução à filosofia através dos filmes. Rio de Janeiro: Rocco, 2006.

COPÉRNICO, Nicolau. As revoluções dos orbes celestes. Lisboa: Fundação Calouste Gunbenkian, 1984.

DELEUZE, Gilles. Lógica do sentido. São Paulo: Perspectiva, 1974.

. Cinema 1: A imagem-movimento. São Paulo: Brasiliense, 1983.

. Cinema 2: a imagem-tempo. São Paulo: Brasiliense, 2005.

DOBB'S Betty. The foundations of Newton's Alchemy. New York: Cambridge University Press, 1984.

JUNG, Carl Gustav. Os arquétipos e o inconsciente coletivo. Petrópolis: Vozes, 2000.

KEYNES, John Maynard. Newton, the man. In: Essays in biography. London: The Macmillan Press Ltd., 1972.

KOPENAWA, Davi. Depoimento recolhido, traduzido do ianomâmi e editado por Bruce Albert, antropólogo do IRD (São Paulo-Paris). In: Brasil 500 anos, experiência e destino. A outra margem do Ocidente. São Paulo: FUNARTE; Instituto Cultural Itaú, 1998.

KOYRÉ, Alexandre. Études newtoniennes. Paris: Gallimard, 1968.

LAWRENCE, David Herbert. Apocalipse, seguido de O homem que morreu. São Paulo: Cia. das Letras, 1990.

MACHADO, Arlindo. Pré-cinema e pós-cinema. Campinas: Papirus, 2013.

NEWTON, Isaac. As profecias de Daniel e o Apocalipse. Édipo: São Paulo, 1950.

NISHITANI, Keiji. Religion and nothingness. Berkley: University of California Press, 1982.

PRIGOGINE, Ilya; STENGERS, Isabelle. A nova aliança. Brasília: Editora Universidade de Brasília, 1984.

RUMI, Mevlana. Masnavi.Buenos Aires: Dervish Ediciones, 1981.

SANTOS, Laymert Garcia dos. Lautréamont e o desejo de não 
desejar. In: NOVAES, A. O desejo. São Paulo: Companhia das Letras, 1990.

SHAKESPEARE, William. Hamlet. Tradução de Millôr Fernandes. São Paulo: L \& PM, 2011.

SIMONDON, Gilbert. Du mode d'existence des objets techniques. Paris: Aubier-Montaigne, 1969.

- Sur la technique. Paris: Presses Universitaires de France, 2013.

TARKOVSKY, Andrei. Esculpir o tempo. São Paulo: Martins Fontes, 1990.

TRISMEGISTO, Hermes. Corpus hermeticum. Discurso de iniciação à tábua de esmeralda. São Paulo: Hemus, 2001.

YATES, Francis. Giordano Bruno e a tradição hermética. São Paulo: Cultrix, 1987.

ZIZEK, Slavoj. Tout ce que vous avez toujours voulu savoir sur Lacan sans jamais oser le demander a Hitchcock. Paris: Navarian, 1988.

Recebido em: 14/03/2017

Aprovado em: 19/12/2017

\section{MÁRCIO BARRETO}

márcio.barreto@ca.unicamp.br

Professor Doutor da Faculdade de Ciências Aplicadas da Universidade Estadual de Campinas, Campinas, São Paulo, Brasil. 